\title{
Violence and Human Prayer to God in Q 11
}

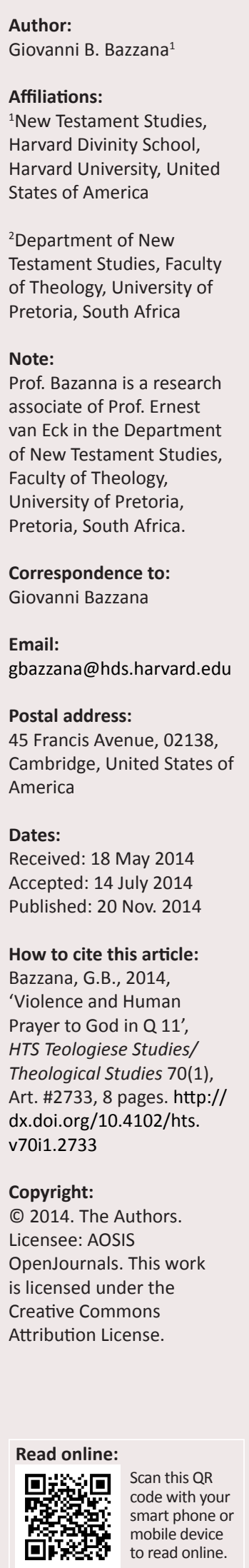

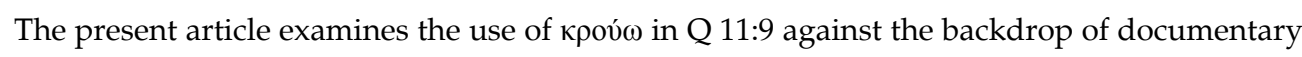
papyri and Greek literary texts that employ the verb to evoke a stock scene of aggression and threat at the door of a house. In the unit 11:2-4, 9-13 the Sayings Gospel employs the same language and gestures in a similar rhetorical situation to advance a complex and ambiguous representation of human agency in prayer, which is not conceived as a mere passive expectancy of God's intervention. This representation fits the socio-cultural profile of village scribes as the authors of $\mathrm{Q}$, given their familiarity with administrative terminology and their acquaintance with widespread and simple rhetorical tropes. Moreover, such an ambiguous stance towards human agency is mirrored in Q's similarly complex understanding of human participation in the establishment of God's $\beta \alpha \sigma \lambda \lambda \varepsilon i ́ \alpha$. Finally, comparable thematic and linguistic features have been detected in the 'parable of the friend at midnight' (Lk 11:5-8), strengthening the hypothesis that the parable might have been part of the Sayings Gospel.

\section{Introduction}

The Sayings Gospel Q was in all likelihood composed in the central decades of the 1st century CE by Galilean village scribes, who wanted to preserve some aspects of Jesus' teaching and to advance their ethical and socio-political agenda (Arnal 2001:157-203, 2013:7-78; Kloppenborg Verbin 2000:214-261). In order to achieve such communicative results, the author(s) of Q had recourse to the terminological and imaginative resources provided by the Jewish scriptures and by the jargon of their profession. By observing the latter's presence in the text of the Sayings Gospel $^{1}$ it is possible to identify the socio-cultural profile of the Q people as Jewish sub-elites who utilised their literacy skills in various capacities (public administrators, estate managers, writers for hire) in the context of Galilean villages (Bazzana 2014).

The present article will focus on the socio-historical and theological implications of the imagery and language used, related to violence, in a specific section of the Sayings Gospel. It has been shown that the author(s) of $\mathrm{Q}$ could deploy terminology drawn from their administrative professional experience to build a negative representation of violence directed against the $Q$ people (Piper 1995:53-74). Similar linguistic and ideological resources are deployed in the Sayings Gospel to also describe certain aspects of the activity of God or of his basileia. Such is the case, for instance, with the image of robbery used to describe the eschatological arrival of the Son of Man in Q 12:39-40. The latter - alongside other Gospel parables that feature 'immoral heroes' (above all, the 'parable of the assassin' in the Gospel of Thomas 1998) - has constantly attracted the attention of scholars puzzled by the theologically problematic imagination of God that they seem to convey (Schramm \& Löwenstein 1986). The present article (by way of the detailed analysis of a Q passage) will show how the second type of deployment of violent language has significant implications for the description of the relationship between God and humans in Q. Moreover, the latter point is consistent with the generally ambiguous way in which the Sayings Gospel portrays the balance between divine and human initiative in the establishment of the eschatological basileia.

The present treatment will begin with the examination of a famous $Q$ verse that is often relatively neglected by exegetes and commentators. Q 11:9 (Mt 7:7; Lk 11:9) is a verse whose structure may

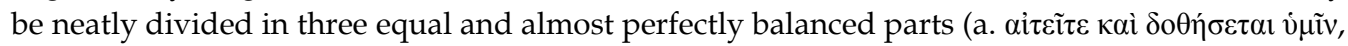

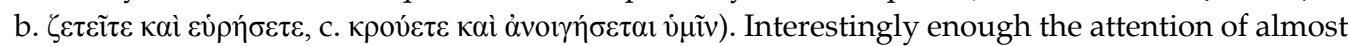
all the readers who have analysed this verse has been drawn to the first two portions, while the last one is usually dismissed or quickly dealt with on the assumption that the preceding parts have already clarified the meaning of the entire verse. Here, I will demonstrate that, if Q 11:9c is compared to a different and broader set of materials, the interpretive result casts a new light on the preceding portions and even allows a more adequate understanding of the entire sub-

\footnotetext{
1.Unless otherwise noted the text of the Sayings Gospel, presupposed in this article, is that of the Critical Edition of $Q$ (Hoffmann, Kloppenborg \& Robinson 2000).
} 
section in which Q 11:9 is included. Accordingly, the article will end with a few considerations on the impact that these results might exert on the overall theological significance of the $Q$ section devoted to prayer ( $Q$ 11:2-4, 9-13), and on the possibility to include in the Sayings Gospel the socalled 'parable of the friend at midnight' (which is extant only in Lk 11:5-8).

\section{Traditional readings of $Q 11: 9$}

In this introductory section I will only summarise a sample of scholarly readings of Matthew 7:7 and Luke 11:9 in order to show the inconsistencies and shortcomings that characterise most of the traditional approaches to the interpretation of the verse at hand.

It is appropriate to start with the examination of some commentaries on Matthew 7:7. In his multivolume analysis of the Gospel, Ulrich Luz opens his treatment by stating that all of the three verbs ('ask', 'seek', and 'knock') 'have a religious dimension in Jewish Christian usage' (Luz 2003:358). Unfortunately, when the Swiss exegete comes to the point of providing evidence in favour of his statement, Luz can refer to an impressive series of parallels from the Hebrew Bible, the Dead Sea scrolls, the Pseudepigrapha, and early Christian texts only for Matthew 7:7a and b. However, Luz must resort to mention only later Talmudic materials when his focus moves specifically onto Matthew 7:7c. Later, the Swiss author goes on to ask the key question: 'Is it the general experience that if they insist enough, people always eventually get what they want?' Such a rhetorical question is inspired in Luz by Joachim Jeremias's much-discussed judgement on the so-called 'parable of the friend at midnight'. The latter pericope immediately precedes Q 11:9 in Luke and was read - in Jeremias's enormously influential book, The parables of Jesus - as a problematic instruction on 'beggar's wisdom' (Jeremias 1954:159-160). According to Luz, the interpretation of the German exegete is not convincing, because - significantly - 'nothing in our text suggests urgent asking or continuous knocking'. Luz's treatment highlights two main problems that are characteristic of the traditional approaches to Matthew 7:7. On the one hand, the exclusive concentration on the search for biblical or para-biblical parallels falls short of explicating the role of Q 11:9c within the verse. On the other hand, most commentators are at pains to dispel the theological danger that might be generated by the idea that human insistence or sense of urgency could influence the success of a prayer addressed to God. In the same vein, for instance, Allison and Davies underscore - with reference to the concluding verse in Matthew 7:11 that 'what is emphasized is not human effort but God's gift' (Allison \& Davies 1988:680).

I. Howard Marshall's commentary on the Greek text of Luke cites only biblical or para-biblical parallels as Luz does for Matthew. Marshall too spends much energy refuting another suggestion of Jeremias's. The latter had advanced the hypothesis that Q 11:9 might be read as hinting at the possibility of obtaining access to the 'heavenly, festal hall' through insistent prayer. The American exegete maintains instead that the verse should be read as envisaging 'an invitation to pray, but not necessarily a command to be importunate in prayer'. Marshall's reading is explicitly designed to dispel the danger that an eschatological reward might be obtained through sheer importunity or, more simply, human activity (Marshall 1978:466-467). Marshall's interpretation is particularly significant, because, in order to force Q 11:9 into the model of a theologically acceptable prayer, he must introduce concepts such as repentance, fear, and sin, which are frankly unwarranted even within the larger context of this pericope in the Gospel of Luke.

In his masterful commentary on the third Gospel, François Bovon devotes a few lines to the last portion of Luke 11:9, and he seems to come closer than anyone else to break away from the traditional dogmatic reading. Bovon compares the reference, to the act of knocking, with another Lukan passage (13:25) in which the condemned knock without success at the door of a householder who does not recognise them. Interestingly enough, the Swiss exegete states that the situation in Luke 11:9 is similar to that represented in Luke 13:25 with only one minor difference: in 11:9 the text does not make explicit any condition that would put those who knock in the position of being granted access. Ultimately, any positive result depends on the human trust in God's mercy:

Der Text hier gibt keinerlei Bedingung für den Erfolg der Unternehmung an. Er is ein Aufruf zumVertrauen, zur Initiative von 'euch', das heißt derer, denen der Glaube und das rechte Handeln gegenüber Gott und den Nächsten zueigen sind. (Bovon 1994:153)

Such hesitancy between 'enterprise or initiative' on the one hand and 'trust' on the other expresses quite clearly Bovon's struggle to find a suitable interpretive framework for Luke 11:9. The fact that he resorts to drawing a comparison with another similar verse - but opposite in its outcome - from the Gospel of Luke serves more to highlight the open questions than to provide an answer to them.

The focus on prayer is retained in the last exegetical example, drawn from Ronald Piper's very insightful reconstruction of the line of argument developed by $Q$ in 11:9-13. Piper summarises very carefully both the meaning of and the interpretive problems still present in the pericope. Firstly, Piper notes that 'the scope of what is encouraged and promised is almost embarrassing', underscoring the magnitude of the role that the text seems to attribute to human action through prayer. Secondly, Piper observes a point to which I will return later. The change from $\delta$ o $\theta \dot{\sigma \varepsilon \tau \alpha l ~[' i t ~ w i l l ~ b e ~ g i v e n '] ~ i n ~ v e r s e ~}$ 9 to $\lambda \alpha \mu \beta \alpha ́ v \varepsilon ı$ ['receives or takes'] in verse 10 should not be overlooked, as this is the only semantic variant between the otherwise perfectly parallel verses and, because it 'diminishes any suggestion of the theological significance of the passive' (Piper 1994:131-137).

Piper's reading highlights some of the ambiguities still present in Q 11:9-10. In the next section I will demonstrate 
that they can be explained with recourse to a different set of comparative materials.

\section{Q 11:9 in the Light of Documentary Papyri}

A first step towards offering an alternative explanation is to shift attention away from an exclusive focus on biblical parallels, which are of course important to understand $Q$ 11:9a and b, but are manifestly unhelpful when one tries to address Q 11:9c. I will start with documentary papyri, as these offer an intriguing entry point for this analysis, and I will then include other Greek materials that will help to sketch a more complete picture.

The verb кpovi literary record and thus is not often employed in documentary papyri. However, given the present context, an occurrence in P.Lond 72009 (Philadelphia, 245-244 BCE) seems particularly interesting 2 :

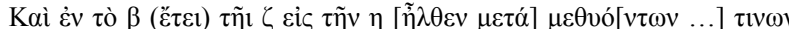

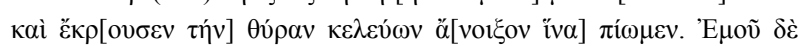

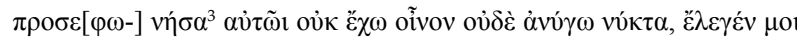

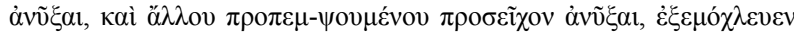

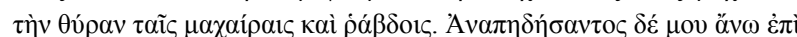

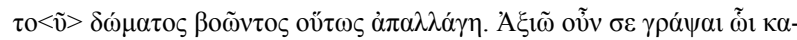
$\theta \eta ́ \kappa \varepsilon เ ~ \dot{\alpha} \pi$ Eủiúxє1.

[And in the second (year) [...], on the seventh (day) at the eighth (hour) he came with some [...] drunkards and he knocked on the door ordering: Open, that we may drink! When I answered: I have no wine and that I do not open at night, he told me to open and, when another (guy) passed by, they both proceeded to open by forcing the door with swords and sticks. When I started up to the roof (and) I cried (for help), thus he left. Therefore, I ask you that you write to whom it may concern to have (him) sent to you so that, if what I write is truthful, I may receive justice. Be well.]

Many features of this complaint recall the short parable which appears in Luke 11:5-8, but I will come back to this additional comparison at the end of the essay. For the time being, it will suffice to note that a key term in the complaint is $\dot{\alpha} v o i ́ \gamma v 0 \mu$ ['to open'], which is obviously connected with the request to open the door of the brewery. The verb is admittedly very common and, thus, finding it in Q 11:9c does not mean much by itself. However, the most interesting feature in this petition is the fact that the assailant, before attempting to

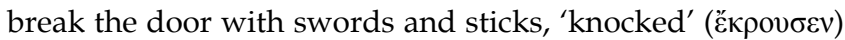
on it. The pair formed by 'knocking' and 'opening' is the same that appears in the $\mathrm{Q}$ text and the coupling of the two terms renders the suggested comparison more meaningful. Moreover, it is worth noting that in P.Lond 2009 the situation is immediately characterised by violence or, at the very least, restlessness on the part of the person who is knocking. That the entire scene is depicted employing these harsh colours may be confidently assessed on the basis of the beginning of

2.Documentary papyri are cited with reference to the Checklist of Greek, Latin Demotic, and Coptic Papyri, Ostraca, and Tablets (available on-line at http://library. duke.edu/rubenstein/scriptorium/papyrus/texts/clist.html).

3.Read $\pi \rho \circ \sigma \varphi \omega v \eta ́ \sigma \alpha v \tau o$ the short text, because the would-be customer does not by any means 'ask politely' to enter the brewery, but 'orders' ( $\varepsilon \varepsilon \lambda \varepsilon v ́ \omega v)$ that the door be opened.

P.Lond 2009 is not an isolated papyrological instance, because already James Moulton had indicated this, as a

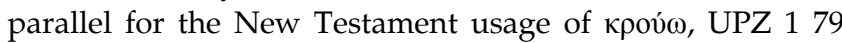
(Memphis, 159 BCE). This unusual document has been republished as C.Ptol.Sklav 248 and it contains a narration of the dreams of the Egyptian Nektembes. The summary nature of the accounts renders particularly difficult their interpretation and the investigation of their meaning for the people involved. However, as far as the issue at hand is concerned, only the third dream (in lines 5-13), which Nektembes experienced on 05 Pharmouthi, has a specific relevance. Nektembes relates an instance when he saw Ptolemaios, from whom the dreams are collected and written down, walking in a road with a sword in his hands: Ptolemaios knocks on the door of presumably his own house

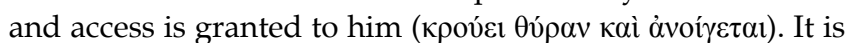
noteworthy that in this instance the atmosphere is also quite tense, because a physical confrontation ensues and a slave (or Nektembes possibly posing as a slave in the dream) closes the tale with a sort of wisdom saying: 'A master does not kill

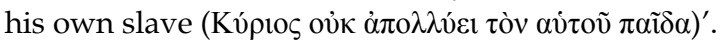

One can suggest that the tension emerging in both these appearances of кроv́ $\omega$ depends on the fact that the verb has the meaning of 'knocking with violence'. Such valence is not restricted to the two early Ptolemaic documents just quoted, but resurfaces consistently at later dates. A telling example comes from an ostracon from Mons Claudianus (O.Claud 1119 [138 or $\left.161 \mathrm{CE}^{4}\right]$ ), in which the verb is employed in reference to a wounded eye.

The meaning of крои́ influences also the usage of its

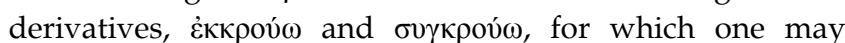
mention a couple of interesting examples.

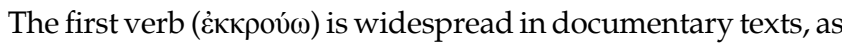
its main meaning refers to 'deducting' an amount of money or kind from a total in accounts or deeds of loan. However, some occurrences have a different nuance. In particular, BGU 31007 (243 or 218 BCE, according to the dating in Ziegler 1994:160) recalls the London papyrus quoted above. BGU 1007 is an anonymous petition addressed to a royal scribe in the 21st year either of Ptolemy III or Ptolemy IV. The author complains that

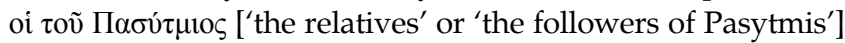
broke into his house while he slept. Although the papyrus is preserved in a fragmentary condition, it is not difficult to imagine the vividly described scene. The assailants kick in the

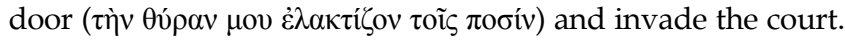
At this point, having heard the tumult, the unnamed writer of the petition comes down from upstairs and asks for help

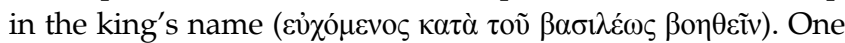
can gather from the remains of the text that someone comes to the rescue and the attackers flee, while the petition probably

4.The dating follows the discussion in O.Claud 2, p. 277 
came to its end with a list of the damaged properties, amongst

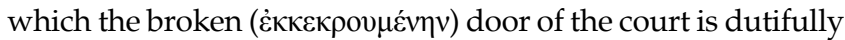
mentioned $^{5}$. In another complaint (P.Tebt 146 ), presented in $113 \mathrm{BCE}$ to Menches the village scribe of Kerkeosiris, Harmysios reports about a burglary that has taken place in his house. Pyrrichos and Herakleios, inhabitants of the same

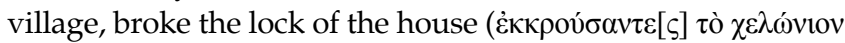

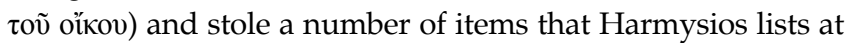
the end of the document.

ChrWilck 11a (Pathyris, after 25th September 123 BCE) is a letter dated with reference to the complaint preserved by fragment $b$, which confirms that the events took place in the 48th year of Ptolemy VIII's reign. The papyrus contains a very vivid illustration of a real 'war' waged between the inhabitants of Krokodilopolis and those of Hermon. The latter, in order to damage the agricultural works of their opponents, destroy a number of dikes that are supposed to guarantee the appropriate flooding of the fields. The confrontation escalates in a full-fledged battle when both villages deploy two actual armies composed of infantrymen and knights: the clash of these armed groups is described by using the verb бvүкрои́

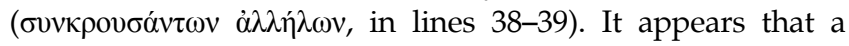
very similar situation might be envisaged behind P.Tebt 1230 (late 2 BCE), a Tebtunis papyrus that has preserved only the body of another document identified by the first editors as a complaint for an assault. The surviving fragment begins with the description of a fight amongst a number of men (oïs kai

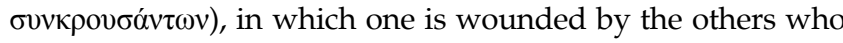
are throwing javelins.

In all likelihood a metaphorical usage of $\pi \rho \circ \sigma \kappa \rho \operatorname{\omega } \omega$ could also be included in this list of verbs indicating violent

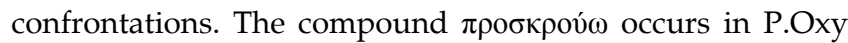
3531 (2 CE), a later letter written by Cornelius to his son Hierax. The father reminds his son that he should not clash with anyone and instead devote his undivided attention to

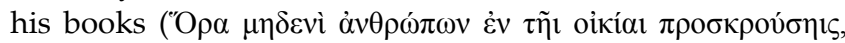

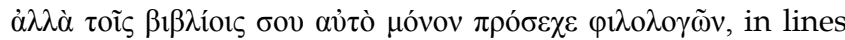
9-11). Such a form of paternal advice is quite common in private letters of this type (Lukaszewicz 1994:97-103).

Finally, before examining how these observations may impact the interpretation of Q 11:9c and of its larger context, it is appropriate to remark briefly on the usage of крои́ $\omega$ in Greek literary materials.

\section{Kpov́ $\omega$ and Avoí $\gamma \omega$ in literary texts}

The examination of documentary papyri has demonstrated that the verb крои́ $\omega$ and its derivatives are often employed to describe violent actions. In those cases in which крои́ occurs in association with $\dot{\alpha} v o$ í $\gamma \omega$ it is used to evoke a situation that is characterised by tension if not even by outright violence, usually involving the forcible attempt to enter a house against the will of its occupants.

5.Geneviève Husson (1983:98) suggests that the final reference (a reconstruction by the editor of the papyrus) may not be to a broken 'door', but more probably to th

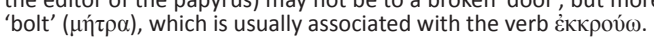

In several New Testament dictionaries and other similar

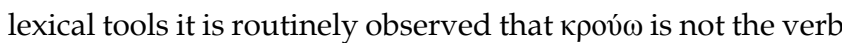
that 'good' classical Greek would have employed to express the act of 'knocking' on a door. Grammarians note that кó $\pi \tau \omega$ would have been the preferred choice in such a context.

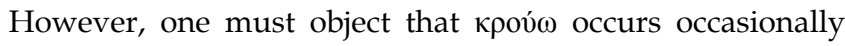
even in classic authors. Moreover, its usage seems consistent with the data derived from the analysis of documentary papyri. There is no space here for a detailed discussion of all

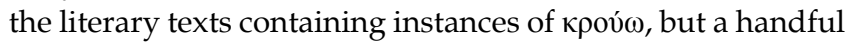
of examples might suffice to clarify the usage pattern.

In Plato's Protagoras, in the prologue of the dialogue (310b), Socrates narrates how Hippocrates happened to visit his house in the middle of the night with exciting news:

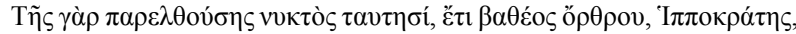

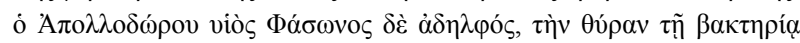

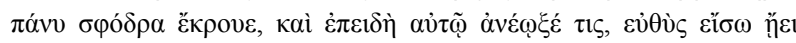

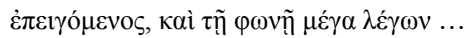

[During the night just past, in the small hours, Hippocrates, son of Apollodorus and brother of Phason, knocked violently at my door with his stick, and when someone opened to him he came hurrying in at once and calling to me in a loud voice saying ...]

The same scene is repeated a few paragraphs later when Socrates himself and Hippocrates seek out Protagoras in Callias's house (314d):

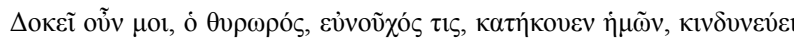

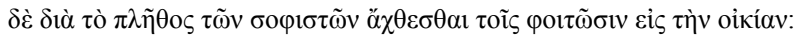

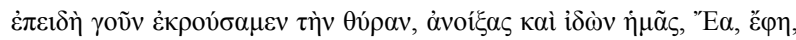

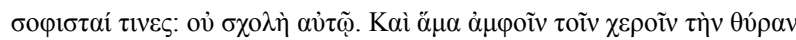

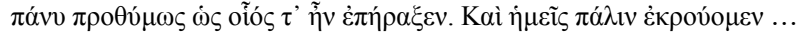

[Therefore, it seems to me that the doorkeeper, a eunuch, overheard us, but he was in danger of becoming annoyed with the callers at the house because of the crowd of sophists. At any rate, when we knocked on the door, he opened it and, on seeing us, Hi, he said, you sophists! [The master] has no free time for you. At the same time, he, seizing the door with both hands, very vehemently shut it with all his might. We tried knocking again ...]

This double scene is certainly more irenic than those found in the documentary papyri discussed above, but its parodic character depends exactly on the same topos that is employed to other rhetorical ends in the complaints. The character of Socrates can depict the visit of Hippocrates as a nuisance, exactly because Plato describes Hippocrates's entrance in Socrates's house with those features that usually are chosen to indicate a forcible act. Along the same lines, readers can understand their visit to Callias's house as a potentially violent act that coherently elicits a strong reaction from the doorkeeper.

It is worth noting that the scene at the door can turn into comedy (as it happens in the Protagoras) as quickly as it can turn into violence. Moreover, the parodic potential is heightened when the author adds a doorkeeper, who is usually an enslaved person and therefore easily understood as a suitable target for jokes. The New Testament too counts 
a comedic scene of this type in Acts 12 with the puzzling encounter between Peter and the slave Rhoda (Harrill 2000:150-157). However, the rhetorical situation can also, obviously, be tweaked in a comic direction in other ways, as in the explicitly lurid variation of the theme in Aristophanes's Ecclesiazusae 317 and 989-990.

The two scenes from Plato's Protagoras have a quite clear violent subtext, but in both cases the potential violence ends up being defused in parody. Through this introduction Plato sets the stage for the ensuing dialogue, in which an argument about virtue and its teachability will be again driven to a parodic conclusion, when each of the two contenders (Protagoras and Socrates) will end up demonstrating the opposite of what they had originally meant to prove. Plato - who evidently much liked this topos - construes a similar scene in Symposium 212c. Immediately after Socrates has ended his report of Diotima's ethereal speech a drunk, Alcibiades, suddenly breaks into Agathon's banquet and provokes an even clearer parodic reversal of the narrative situation. Xenophon (Symposium 1 11) tries to recreate a similar effect in his own version of the banquet dialogue, but the result is, as usual, much more wooden.

One may add that the same violent subtext - unfortunately without parodic reversal in this case - also found its way into the Greek translation of the Bible. In the book of Judges, chapter 19 is occupied with the terrible story of the aggression of a guest in the city of Gibeah. When the inhabitants of Gibeah ask that the host abandon his guest to their wicked desires (v. 22), the scene is described with these words:

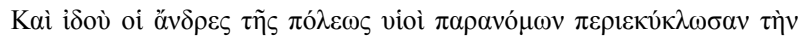

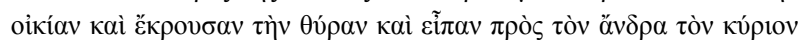

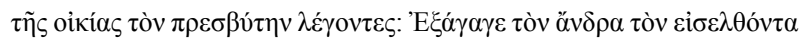

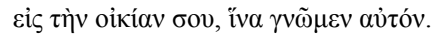

[And then the men of the city, who were sons of violators of the law, surrounded the house and knocked on the door and addressed the elder man, the householder, saying: Lead out the man who entered your house, so that we might know him.]

This is the Greek version preserved by the codex Alexandrinus, while Vaticanus carries a slightly different formulation, which is cast in better Greek, but does not present major divergences as far as the present theme is concerned. Josephus (Jewish Antiquities V 143), in his rewriting of the episode, changes prudishly the identity of the object of the Gabaenes's sexual frenzy and adds amplifications that are mirrored in the legal-administrative language of his time:

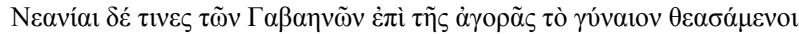

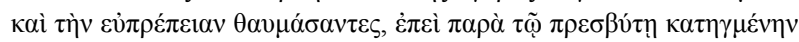

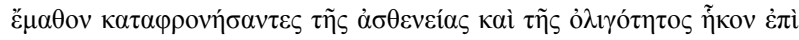

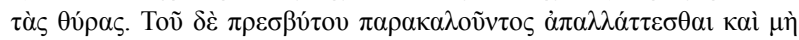

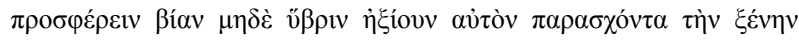

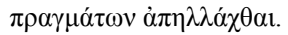

[However, some Gabaene young men, who had observed the woman in the market-place and admired her beauty, after having learned that she was lodging with the old man, despising their weakness and fewness, came to the doors. When the old man appealed to them to depart and to inflict neither unlawfulness nor violence, they demanded that he hand over his woman guest as to be done with the matter.]

The threat of violence implicit in the request of the inhabitants of Gibeah is conveyed as much by the description of the surrounded house as by the employment of the verb крои́ $\omega$.

\section{The interpretation of Q 11:2-4,9-13}

The preceding sections have demonstrated - through a comparison with documentary papyri and Greek literary texts - that Q 11:9c is constructed on the model provided by a scenario that is relatively widespread, both in Greek literature and in Greek bureaucratic writing. In particular, the choice to utilise the verb кроv́ aggressive subtext in a sentence that is too blandly translated as 'knock and it will be opened'. But what are the interpretive consequences for the entire verse $Q$ 11:9 and for the larger context of Q 11:2-4, 9-13?

As observed above, many exegetes struggle to make sense of the fact that Q 11:9 seems to present Jesus as calling the readers of the Sayings Gospel to 'urgency in asking' or to be 'importune in their prayer'. A certain interpretation of Q 11:9a and b may accommodate an exegesis concerned with the dogmatic need to limit human initiative in prayer, but the entire context changes dramatically if one takes seriously the implications of an 'aggressive' or 'urgent' reading of $Q 11: 9 \mathrm{c}$. The very phrasing of the last part of the verse requires a follower of Jesus to act as the assailant did, who is described in P.Lond 7 2009. Prayers and requests addressed to God must have an insistency that is powerfully represented by images evoking physical aggression.

On such grounds one may also look at the following verse in a very different way. Interestingly enough, in Q 11:10a ['for everyone who asks receives'] almost all translators attribute to $\lambda \alpha \mu \beta$ óveเ a passive valence ['to receive'], no doubt because of the influence of the passive $\alpha v o r \gamma \eta \dot{\sigma \tau} \alpha \mathrm{l}$ in the previous verse. Hence, 'it will be opened' is routinely understood as a passivum divinum that would indicate God's initiative in granting human requests. Thus, Allison and Davies read all the passive forms in these two verses as 'divine' (Allison \& Davies 1988:679), but one has already mentioned above Piper's hesitancy to accept such interpretation because of the presence of the active $\lambda \alpha \mu \beta \alpha$ vec. Moreover, a growing number of exegetes are now questioning the methodological opportunity of understanding every passive without explicit agent as 'divine' (Pascut 2012:313-333). An alternative translation could stress the active aspect of $\lambda \alpha \mu \beta \alpha$ óvı ['to take' or, maybe less boldly, 'to acquire'] and, therefore, attempt to emphasise instead of hiding the unique structural discontinuity between the otherwise mirroring of Q11:9 and 10.

A reading that stresses the role of human agency in prayer might complement nicely Piper's understanding of the argument developed in Q 11:9-13. As noted by the British exegete, the two first verses (9-10) offer a gnomic introduction that states the argument by referring to its foundational principle (Piper 1994:131-137). To this observation I would 
add that the general principle is indeed an exhortation for human beings to take the initiative in establishing the kingdom of God, with the full assurance that the outcome of such a bold move will be successful. The unavoidable establishment of the basileia is indeed a prominent theme in Q: for instance, it appears in the pair formed by the parables of the mustard seed and of the yeast in Q 13:18-21. Such an extremely optimistic outlook is neatly connected to the second half of the Lord's Prayer that immediately preceded our passage in $\mathrm{Q}$ (11:2-4), and that already hinted at a human role in initiating God's activity through the equally puzzling formulation of the request for debt relief, in which human forgiveness precedes and conditions God's remittance (Rüegger 2009:21-28).

Finally, apparently only verses 11-13 move the argumentative focus in a different direction. In fact, as noted again by Piper, they provide a buttressing for the exhortation of Q 11:9-10 by confirming that God, who is much better than any earthly father, will certainly meet human initiative with favour and eventual success. By arching back to the representation of God as father that opens the Lord's Prayer, verses 11-13 highlight not only the literary unity of the sub-section, but also its inherent conceptual tension. At the beginning of Q 11 the Sayings Gospel deals with the ambiguities inherent in the relationship between divine authority and human action in prayer, but the final product is less a systematisation than a simpler juxtaposition of two contrasting agencies (Bazzana 2012:16-26). The tension in describing agency in prayer mirrors Q's ambiguous stance on the relationship between divine and human initiative in the establishment of the $\beta \alpha \sigma i \lambda \varepsilon i \alpha$ and, as I have tried to show elsewhere at length, depends on the social location of the $Q$ author(s) on the margins between urban elites and village peasantry (Bazzana 2014).

\section{The friend at midnight (Q 11:5-8)}

The conclusions, of the analysis developed in the preceding paragraphs, lead naturally to a reconsideration of the place of the so-called 'parable of the friend at midnight' between the Lord's Prayer ( $Q$ 11:2-4) and the sayings on prayer $(Q$ 11:9-13):

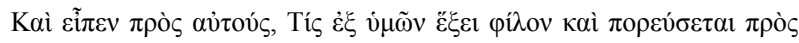

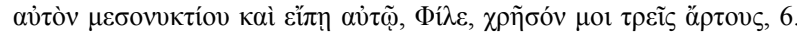

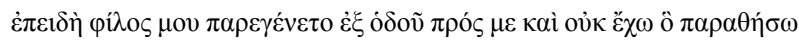

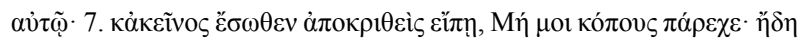

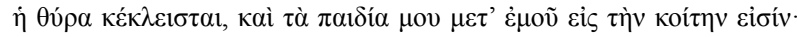

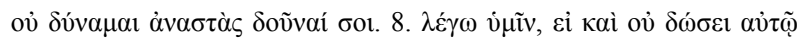

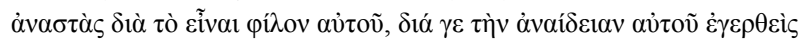
$\delta \omega ́ \sigma \varepsilon เ \alpha u ̛ \tau \tilde{~}$

[And Jesus said to them, Suppose one of you has a friend and you go to him at midnight and say to him, 'Friend, lend me three loaves of bread; for a friend of mine has arrived from the road to my house and I do not have anything to set before him'. And answering from within, he says, 'Do not bother me, the door has already been locked, and my children are with me in bed; I cannot get up and give you anything'. I tell you, even though he will not get up and give him anything because he is his friend, at least because of his shameless aggressiveness he will get up and give him whatever he needs.]

The parable is preserved only in the Gospel of Luke and, thus, usually it is not counted amongst the materials coming from the Sayings Gospel. However, given its position (sandwiched between two groups of $Q$ verses) and its thematic focus on prayer, there have been some attempts to vindicate its preLukan presence in a literary unit encompassing the entirety of Luke 11:2-13 (Catchpole 1983:407-424; Dupont 1958:6373). In any event, it must be judged impossible to establish in a definitive way the original presence of verses 5-8 in the Sayings Gospel, on the basis of the evidence currently at our disposal. The brief reflections presented here are merely aimed at exploring the impact that a new interpretation of Q 11:2-4, 9-13 (as that discussed above) might have on a potential reading of the parable of 'the friend at midnight', when understood as part of the Sayings Gospel.

Both the general interpretation of the parable and the discussion of its possible inclusion in $Q$ depend largely on the meaning that is assigned to o $\alpha \alpha i \delta \varepsilon 1 \alpha$ in verse 8 . The Greek word has literally the meaning of 'shamelessness' and as such it carries a clear negative valence. On the one hand, this negative connotation creates problems for exegetes, as the parable seems to employ this image to describe the attitude that humans ought to have in prayer (if the friend who is called on at midnight is identified with God). To avoid this conclusion many commentators attempt to demonstrate that $\dot{\alpha} v \alpha i \delta \varepsilon 1 \alpha$ has in fact a positive valence too, and that it should be read into the occurrence in Luke 11:8. However, Klyne Snodgrass has demonstrated that the positive meaning is

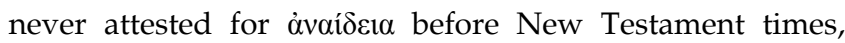
and that actually it surfaces only in the writings of early Christian authors who are quite obviously concerned with the exegetical problem created by this approving reference to 'shamelessness' (Snodgrass 1997:505-513). Snodgrass's conclusion is even more convincing in light of what has been demonstrated above with reference to Q's 'immoral' imagination of God's actions and - in the specific case of 'knocking' in Q 11:9 - of human attitudes towards God in prayer.

On the other hand, several exegetes note that the appeal to $\alpha v \alpha i \delta \varepsilon 1 \alpha$ in verse 8 seems to create a contrast with the focus on 'friendship' that characterises the preceding verses 5-7. On these grounds, and again in order to avoid the interpretive conundrum mentioned in the previous paragraph, it is often hypothesised that an 'original' form of the parable contained only verses 5-7 and was centred on 'friendship', while verse 8 was added by the Lukan redactor in order to underscore the theme of insistence in prayer that appears again in the Gospel in the so-called 'parable of the unjust judge' in Luke 18:1-8 (Leonardi 1980:263-287). Nevertheless, this redactional-critical proposal has several problems. Firstly, it uses as its foundation the idea of a narrative inconsistency that is not self-evident, but in turn 
depends on the assumed existence of the redactional seam that it should demonstrate in the first place. In the case at hand, the unwarranted assumption is that the flow of the parable does switch from a focus on friendship in verses 5-7 to one on shamelessness in verse 8 . In fact nothing in the short narrative is intended to communicate the idea that God is a friend of human beings (however appealing this notion might be for modern exegetes). As forcefully stated by Klyne Snodgrass, 'the parable does not teach that God is a friend', but the friendship imagery is evoked only to show that any human request will be satisfied, regardless of the polite or shameless way in which it is formulated (Snodgrass 1997:513; contra Merz 2007:556-563).

Secondly, the routine association between the ending of the parable in verse 8 and the story of the unjust judge (Lk 18:1-8) is compelling only to a certain degree. Indeed, the two stories present as many similarities as differences, most prominently in the nature of the characters to whom the requests are addressed in the first place. While the main figure of Luke 18:6 is characterised negatively as being

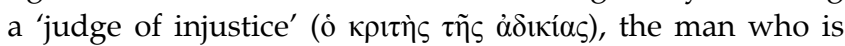
called upon in the middle of the night is a 'friend' ( $\varphi$ í $\lambda \circ \varsigma$ ) and thus assumed to respond positively to the demand for bread. Furthermore, the theme of 'friendship' is clearly a favourite of Luke amongst the Synoptics and thus it could be easily considered evidence of a redactional tendency (the hearers of Jesus are called 'friends' in Lk 12:4 and the Son of Man is called the 'friend' of publicans and sinners by his detractors in Lk 7:34, just to mention two examples).

Be this as it may, the use of $\alpha \dot{v} \alpha i \delta \varepsilon 1 \alpha$ in Luke 11:8 is routinely invoked also to demonstrate that the parable of the friend at midnight (with its suggestion of shameless and insistent prayer) could not have been part of a Sayings Gospel's unit, focused on prayer as passive trust in God's faithfulness. However, the preceding observations on the valence of 'knocking' have shown that a more aggressive or at least active reading of Q 11:9-10 is possible and warranted. Interestingly enough, Snodgrass has pointed to literary occurrences of $\dot{\alpha} v \alpha i \delta \varepsilon 1 \alpha$ in which the word takes a meaning that is less linked to a psychological attitude [as in 'shamelessness'] than to illegal and criminal actions. For instance, Pausanias mentions two stones in the vicinity of Athens's Acropolis that had the name respectively of $\alpha v \alpha i \delta \varepsilon 1 \alpha$ and $0 \beta \beta p 1 \varsigma$ ['violence'] and were the location where trials were held (Snodgrass 1997:508). Indeed, documentary papyri offer additional proof of this

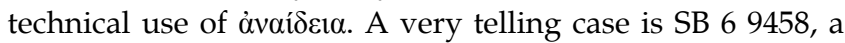
complaint coming from Tebtunis and dated to the second half of the 2nd century CE:

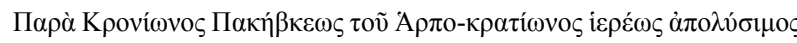

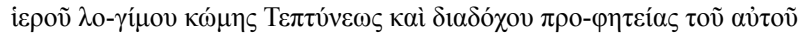

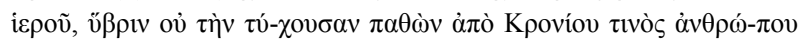

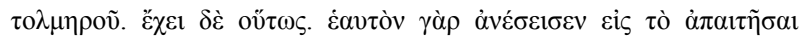

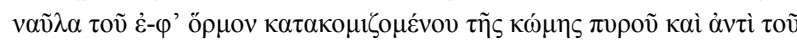

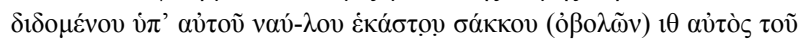

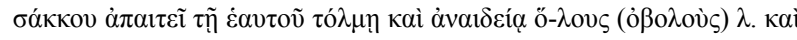

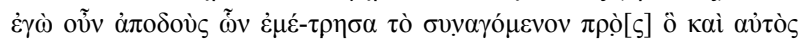

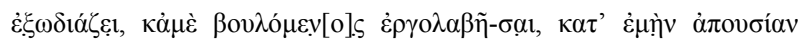

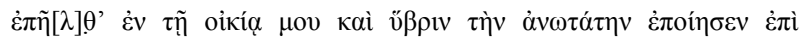

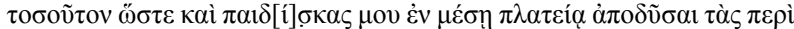

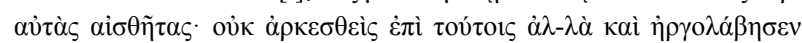

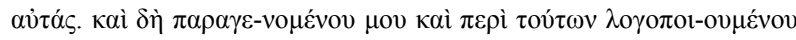

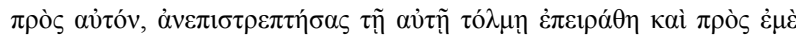

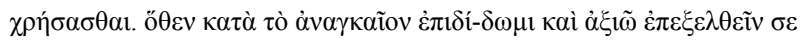

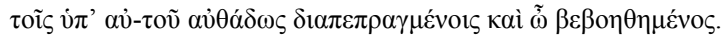

[From Kronios, son of Pakebkis, son of Harpokration, a priest free from liturgies of the notable shrine of the village of Tebtunis and heir of the prophecy of the same shrine, who suffers a nonnegligible offense from a certain Kronion, a reckless man. This is the matter. This Kronion had himself appointed to receive the payment of the transportation tax for the grain brought to the village harbor and, instead of the payment of 19 oboloi for each sack advanced by him, he charges the full amount of 30 oboloi for each sack because of his recklessness and shamelessness. And despite the fact that I pay the sum corresponding to [the amount of grain] that I measured, to which he added full charges, since he wants to take advantage of me, he came upon my house while I was absent and he caused the utmost offense to the extent that he has my female servants give him the clothes that they had on in the middle of the square. But he was not satisfied with the clothes and he took advantage of them too. When I came back and tried to talk to him about these events, he paid no attention and - in his recklessness - tried to assault me too. Therefore, I must give in out of necessity and ask you to proceed against what he has stubbornly done and thus I might be helped.] (Welles 1957:103-111)

In the rhetorical situation of this complaint, Kronios

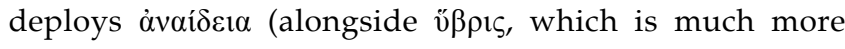
common in documentary texts) to indicate more than a shameless action, actually an illegal abuse and a forcible encroachment on the rights of someone else. In the very interesting vignette sketched by Kronios in this message to an unnamed official one can even see a reckless trespass into a house that cannot fail to recall the $Q$ scenes examined in the present study. The same use of $\alpha v \alpha i \delta \varepsilon 1 \alpha$ can be observed in other documents too. SB 6 9105, 8-13 (Arsinoites, 01 August $198 \mathrm{CE}$ ) is another plea addressed to a police officer by a Roman citizen (Barns 1949:295-

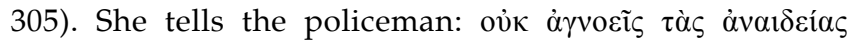

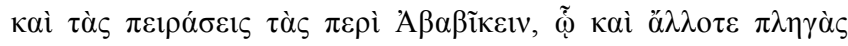
$\dot{\varepsilon} \pi \varepsilon \dot{\varepsilon} \theta \kappa \alpha \varsigma \dot{\alpha} v \alpha 1 \delta \varepsilon ı \tilde{\omega} v \varepsilon \check{v} v \varepsilon \kappa \varepsilon v$ ['You do not ignore the shameful actions and the attempts made concerning Ababikis, for which actions in other occasions you gave him a beating']. In another complaint, SB 69421 (Oxyrhynchos, 3 century CE), Aurelius reports that a certain Didyme,

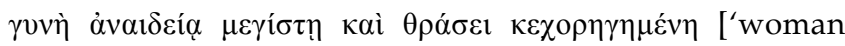
abundantly supplied with the greatest shamelessness and arrogance'], has addressed him with speakable and unspeakable words while he was sitting with his relatives in front of his house during the evening (Eitrem \& Amundsen 1954:30-33).

This brief examination of the technical legal use of $\alpha v \alpha i \delta \varepsilon \imath \alpha$ in documentary writings demonstrates that the occurrence in Luke 11:8 resembles that of крои́ in Q 11:9 which is surveyed above. In both cases the text compares human requests to God to aggressive and even illegal actions. Given the number of such 'immoral' comparisons detected 
in the Sayings Gospel, this observation becomes relevant evidence to claim the parable of the friend at midnight for $Q$ and renders the question, whether the positive use of $\dot{\alpha} v \alpha i \delta \varepsilon 1 \alpha$ starts with Luke or in the early Christian reception, rather immaterial (Waetjen 2001:703-721). In this case, as in that reviewed above, the village scribes who authored the Sayings Gospel had recourse to the imaginative and linguistic resources of their trade, to express in a narrative form their ambiguous stance with reference to human agency in the establishment of God's eschatological $\beta \alpha \sigma \imath \lambda \varepsilon i ́ \alpha$.

\section{Conclusion}

The present aticle has examined the use of крои́ in Q 11:9 against the backdrop of documentary papyri and Greek literary texts, that employ the verb to evoke a stock scene of aggression and threat at the door of a house. In the unit 11:24, 9-13 the Sayings Gospel employs the same language and gestures towards a similar rhetorical situation, to advance a complex and ambiguous representation of human agency in prayer, which is not conceived as a mere passive expectancy of God's intervention. This representation fits the sociocultural profile of village scribes as the authors of $Q$, given their familiarity with administrative terminology and their acquaintance with widespread and simple rhetorical tropes. Moreover, such an ambiguous stance towards human agency is mirrored in Q's similarly complex understanding of human participation in the establishment of God's $\beta \alpha \sigma i \lambda \varepsilon i \alpha$. Finally, comparable thematic and linguistic features have been detected in the 'parable of the friend at midnight' (Lk 11:5-8) strengthening the hypothesis that the parable might have been part of the Sayings Gospel.

\section{Acknowledgements Competing interests}

The author declares that he has no financial or personal relationship(s) that might have inappropriately influenced him in writing this article.

\section{References}

Allison, D.C. \& Davies, W.D., 1988, A critical and exegetical commentary on the gospel according to Saint Matthew, vol. 1, T\&T Clark, Edinburgh.

Arnal, W.E., 2001, Jesus and the village scribes: Galilean conflicts and the setting of $Q$, Fortress Press, Minneapolis.

Arnal, W.E., 2013, 'The trouble with Q', Forum: Foundations and Facets 3, 7-78.

Barns, J., 1949, 'Three Fayûm Papyri', Chronique d' Egypte 24, 295-305.

Bazzana, G.B., 2012, 'Neo-Marxism, language ideology, and the New Testament', The Bible and Critical Theory 8, 16-26.

Bazzana, G.B., 2014, Kingdom of bureaucracy: The political theology of village scribes in $Q$, Peeters, Leuven.

Bovon, F., 1994, Das Evangeliumnach Lukas, vol. 2, Neukirchener, Neukirch.

Catchpole, D.R., 1983, ' $Q$ and "The friend at midnight" (Luke xi. 5-8/9)', Journal of Theological Studies 34, 407-424. http://dx.doi.org/10.1093/jts/34.2.407

Dupont, J., 1958, Les Béatitudes, I, Le problème littéraire: les duex versions du Sermon sur la montagne et des Béatitudes, 2nd edn., Bruges, Abbaye de Saint-André.

Eitrem, S. \& Amundsen, L., 1954, 'Complaint of an assault, with petition to the police', arrill. J.A., 2000 'The dramatic function of the running slave Rhoda (Acts 12:13-16):

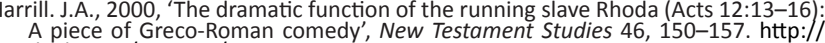
A piece of Greco-Roman comedy', New
dx.doi.org/10.1017/S0028688500000096

Hoffmann, P., Kloppenborg, J.S., \& Robinson, J.M., 2000, The critical edition of $Q$, Peeters, L'euven.

Husson, G., 1983, OIKIA. Le vocabulaire de la maison privée en Égypted' après les papyrus grecs, Sorbonne, Paris.

Jeremias, J., 1954, The parables of Jesus, SCM, London.

Kloppenborg Verbin, J.S., 2000, Excavating Q: The history and setting of the Sayings Gospel, Fortress, Minneapolis.

Leonardi, G., 1980, 'Cercate e troverete ... lo Spirito Santo nell'unità letteraria d Luca 11, 1-13', in Quaerere Deum: Atti della XXV settimana biblica, pp. 263-287, Paideia, Brescia.

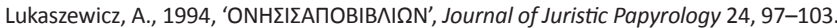
Luz, U., 2003, Matthew: A commentary, vol. 1, Fortress, Minneapolis.

Marshall, I.H., 1978, The Gospel of Luke: A commentary on the Greek text, Eerdmans, Grand Rapids.

Merz, A., 2007, 'Freundschaft verpflichtet (Vom bittenden Freund)', in R. Zimmermann (ed.), Kompendium der Gleichnisse Jesu, pp. 556-563, Gütersloher, Gütersloh,

Pascut, B., 2012, 'The So-Called Passivum Divinum in Mark's Gospel', Novum Testamentum 54, 313-333. http://dx.doi.org/10.1163/15685365-12341400

Piper, R.A., 1994, 'Matthew 7:7-11 par. Luke 11:9-13: Evidence of Design and Argument in the Collection of Jesus' Sayings', in J.S. Kloppenborg (ed.), The shape of Q: Signal essays on the Sayings Gospel, pp. 131-137, Fortress, Minneapolis.

Piper, R.A., 1995, 'The language of violence and the Aphoristic Sayings in Q: A study of and social studies on the Sayings Gospel Q, pp. 53-73, Trinity International, Valley Forge.

Rüegger, H.-U., 2009, 'Sollen wir vergeben haben? Philologische Annäherung an (in A TVZ, Zürich.

Schramm, T., \& Löwenstein, K, 1986, Unmoralische Helden: anstössige Gleichnisse Jesu, Vandenhoeck \& Ruprecht, Göttingen.

Snodgrass, K., 1997, 'Anaideia and the Friend at Midnight (Luke 11:8)', Journal of Biblical Literature 116, 505-513. http://dx.doi.org/10.2307/3266672

Waetjen, H.C., 2001, "The subversion of "world" by the parable of the friend at midnight', Journal of Biblical Literature 120, 703-721. http://dx.doi. org $/ 10.2307 / 3268267$

Welles, C.B., 1957, 'Complaint from a Priest of Tebtunis Concerning Grain Transportation Charges of the Late Second Century', Etudes de papyrology 8, egler, R., 1994, 'Bemerkungen zur Datierung dokumentarischer Papyri und Ostraka', ZeitschriftfürPapyrologie und Epigraphik 114, 157-161. 